Jumal Penditian danEvaluas Penddikan

\title{
IMPLEMENTASI EVALUASI MODEL KIRKPATRICK PADA PERKULIAHAN MASALAH NILAI AWAL DAN SYARAT BATAS
}

\author{
Syamsu Qamar Badu \\ FMIPA Universitas Negeri G orontalo \\ syamsu@ung.ac.id
}

\begin{abstract}
Abstrak
Penelitian ini bertujuan untuk mendapatkan gambaran tentang implementasi Evaluasi Model Kirkpatrick pada Program Pembelajaran Matakuliah Masalah Nilai Awal (MNA) dan Syarat Batas. Dari empat level untuk Evaluasi Model Kirkpatrick masing-masing dilakukan penilain dengan alat penilaian yang berbeda. Penilaian kinerja digunakan untuk menilai hasil kerja atau proyek mahasiswa. Metode penelitian ini adalah penelitian deskriptif kualitatif. Sampel dalam penelitian ini adalah mahasiswa Jurusan Pendidikan Matematika Fakultas Matematika dan Ilmu Pengetahuan Alam Universitas Negeri Gorontalo berjumlah 58 orang. Data dalam penelitian ini dijaring menggunakan angket dan dilakukan pengujian reliabilitas dengan Crombach's Alpha. Evaluasi belajar mahasiswa diperoleh dengan menggunakan rubrik penilaian kinerja. Hasil penelitian menggambarkan Evaluasi Model Kirkpatrick pada Program Pembelajaran Matakuliah Masalah Nilai A wal (MNA) dan Syarat Batas sangat efektif.

Kata Kunci: Evaluas Modd Kirkpatridk, Asemmen Kineja, Masalah Nilai A wal dan Syarat Batas
\end{abstract}

102 - Jumal PenditiandanEvaluas Penddikan Edisi D ies Natalis ke-48 UNY 


\title{
THE IMPLEMENTATION OF KIRKPATRICK'S EVALUATION MODEL IN THE LEARNING OF INITIAL VALUE AND BONDARY CONDITION PROBLEMS
}

\author{
Syamsu Qamar Badu \\ FMIPA Universitas Negeri G orontalo \\ syamsu@ung.ac.id
}

\begin{abstract}
This research is aimed at describing the implementation of the implementation of Kirkpatrick's evaluation model in the learning of Initial Value and Bondary Condition Problems. Four each of the four different levels in the model, an evaluation was conducted using different instruments. A performance evaluation was to assess the students' product or project. This was a qualitative descriptive study involving 58 students of Mathematics Department, Faculty of Mathematics and Natural Sciences, State University of Gorontalo as the sample. The data were collected by questionnaire; the reliability was tested through Cronbrach's alpha. Students' learning achievement was scored using a performance rubric. The study shows that Kirkpatrick's Evaluation Model for the leaming program for Initial Values and Boundary Condition Problems is very effective.
\end{abstract}

Keywords: Kirkpatridk's Evaluation Modd, Peformance Assessment, Initial V alueandBaundaryCondition Prdblems 
Jumal Penditian danEvaluas Penddikan

\section{Pendahuluan}

Matakuliah Masalah Nilai Awal dan Syarat Batas merupakan matakuliah wajib yang ada di Jurusan Pendidikan Matematika Fakultas Matematika Universitas Negeri Gorontalo. Aplikasi dari matakuliah ini berkaitan dengan komputasi dan sistem pemodelan. Mengingat karakteristik matakuliah yang sangat kompleks, maka diperlukan suatu bentuk evaluasi program pembelajaran yang dapat mengungkap seluruh kemampuan/potensi yang dimiliki oleh mahasiswa khususnya yang berkaitan dengan standar kompetensi matakuliah ini. Usaha peningkatan kualitas akademik dapat ditempuh melalui peningkatan kualitas pembelajaran dan kualitas model evaluasi. Sistem pembelajaran yang baik akan menghasilkan kualitas belajar yang baik pula, hal ini menunjukkan keterkaitan antara dua aspek tersebut.

Aspek evaluasi tidak bisa diabaikan oleh seorang dosen maupun guru. Evaluasi merupakan suatu proses yang kontinu yang menjadi dasar dari keseluruhan kegiatan pembelajaran yang baik. Evaluasi merupakan proses penetapan nilai dari suatu program yang telah ditetapkan. Secara umum evaluasi dapat diartikan sebagai proses sistematis untuk menentukan nilai sesuatu (tujuan, kegiatan, keputusan, unjuk kerja, proses, orang, maupun objek) berdasarkan kriteria tertentu. D alam kegiatan pembelajaran, evaluasi dapat didefinisikan sebagai suatu proses sistematik dalam menentukan tingkat pencapaian tujuan pembelajaran yang telah ditetapkan.

National Study Committee on Evaluation dalam Stark dan Thomas (1994:12) menyatakan bahwa evaluation is the process of ascertaining the decision of concern, selecting appropriate information, and collecting and analyzing information in order to report summary data useful to decision makers in selecting among alternatives. Evaluasi merupakan suatu proses atau kegiatan pemilihan, pengumpulan, analisis dan penyajian informasi yang dapat digunakan sebagai dasar pengambilan keputusan serta penyusunan program selanjutnya. Hal ini dipertegas oleh G riffin dan Nix (1991:3) menyatakan: Measurement, assessment, and evaluation are hierarchial. The comparison of observation with the criteria is a measurement, the interpretation and description of the evidence is an 
assessment and the judgement of the value or implication of the behavior is an evaluation.

Evaluasi menupakan salah satu bagian yang tidak terpisahkan dari kegiatan pembelajaran matematika. Pendidik dapat melakukan banyak hal untuk mengumpulkan informasi mengenai tingkat penguasaan mahasiswa, seperti memberikan tes, tugas, mengajukan pertanyaan secara lisan, mengamati aktivitas saat kegiatan belajar mengajar, dan portofolio. Aktifitas itu dilakukan tidak hanya untuk menentukan nilai mahasiswa tetapi juga untuk meningkatkan kualitas pembelajaran matematika.

Evaluasi pembelajaran perlu dilakukan secara menyeluruh dan berkesinambungan yang mencakup penilaian terhadap proses belajar dan penilaian terhadap hasil belajar. Salah satu faktor yang penting untuk mencapai tujuan pendidikan adalah proses pembelajaran yang dilakukan, sedangkan faktor lain yang penting untuk efektivitas pembelajaran adalah faktor evaluasi dan penilaian, baik terhadap proses maupun hasil pembelajaran. Penilaian dapat mendorong peserta didik untuk lebih giat belajar secara terus menerus dan juga mendorong pendidik untuk lebih meningkatkan kualitas proses pembelajaran.

Salah satu komponen utama dalam sistem pendidikan adalah unsur asesmen. Penilaian tidak hanya memberikan gambaran atau informasi tentang tingkat keberhasilan atau penguasaan mahasiswa terhadap materi yang diajarkan, tetapi juga memberikan umpan balik terhadap program pendidikan yang dilaksanakan. Proses penilaian dalam pembelajaran dilakukan dalam rangka mengambil keputusan tentang penguasaan mahasiswa setelah mengikuti proses belajar mengajar. Selain itu, untuk memperoleh gambaran tentang ketepatan strategi atau pendekatan pembelajaran yang digunakan.

Sehubungan dengan hal tersebut, maka di dalam pembelajaran dibutuhkan tenaga pendidik yang memiliki kemampuan tidak hanya mengajar dengan baik tetapi juga mampu melakukan evaluasi dengan baik dan efektif berdasarkan karakteristik matakuliah yang diajarkan. Kegiatan evaluasi sebagai bagian dari program pembelajaran perlu lebih dioptimalkan. Evaluasi tidak hanya bertumpu pada hasil belajar, tetapi juga perlu terhadap input, output, maupun kualitas proses pembelajaran. D alam 
dunia pendidikan dan proses pembelajaran, peranan media teknologi informasi tidak bisa diabaikan. Pemanfaatan media seharusnya merupakan bagian yang harus mendapatkan perhatian dosen/guru dalam setiap kegiatan pembelajaran. Kegiatan penilaian hendaknya tidak hanya mengandalkan pemberian tes tradisonal.

Kelemahan penggunaan tes tradisional (paper and penil teet) yang digunakan sebagai satu-satunya alat pengambilan keputusan tentang siswa diantaranya hanya menilai pengetahuan ilmiah, penilaian cenderung pada dimensi hasil belajar terbatas (pengetahuan atau keterampilan), tidak dapat digunakan untuk menilai penalaran ilmiah mendalam, dan seringkali kurang menunjukkan kemampuan siswa yang sesungguhnya, (Mokhtari et al.,1996). Beberapa kelemahan lain tes tradisional adalah setiap soal yang digunakan umumnya hanya memiliki satu jawaban, tidak berfokus pada proses tetapi pada hasil akhir, tidak mengungkap proses berpikir siswa dan tidak mengukur semua aspek dalam proses belajar mengajar.

Brikerhoff dalam Mardapi (2000) mengemukakan dalam pelaksanaan evaluasi terdapat tujuh elemen yang harus dilakukan, yaitu: 1) fousing the evaluation (penentuan fokus yang akan dievaluasi), 2) designing the exaluation (penyusunan desain evaluasi), 3) colleting information (pengumpulan informasi), 4) analyzingand interpreing(analisis dan interpretasi informasi), 5) repatinginfomation (pembuatan laporan), 6) managing ealuation (pengelolaan evaluasi), dan 7) evaluating exaluation (evaluasi untuk evaluasi). Berdasarkan pengertian tersebut menunjukkan bahwa dalam melakukan evaluasi, evaluator pada tahap awal harus menentukan fokus yang akan dievaluasi dan desain yang akan digunakan.

Adapun tujuan evaluasi adalah untuk memperoleh informasi yang akurat dan obyektif tentang suatu program yang telah direncanakan dan dilaksanakan. Informasi tersebut dapat berupa proses pelaksanaan program, dampak/ hasil yang dicapai, efisiensi. Hasil evaluasi dapat juga dijadikan tolak ukur apakah program tersebut berhasil atau tidak, dapat dilanjutkan atau dihentikan, serta dapat dijadikan pijakan untuk menyusun program lanjutan.

Berbagai model evaluasi yang telah dikembangkan dan sangat populer dan banyak dipakai sebagai strategi atau pedoman kerja dalam 
pelaksanaan evaluasi program pembelajaran diantaranya 1) Evaluasi Model Kirkpatrick (Kirkpatridk Four Ledes Evaluation Modd), 2) Evaluasi Model CIPP (Context, Imput, Prosess, and Product), dan 3) Evaluasi Model Stake (Modd Caintenance). Dari empat model ini masing-masing memiliki karakteristik yang berbeda. Dalam penelitian ini lebih difokuskan pada Evaluasi Model Kirkpatrick

Ditinjau dari sasarannya dalam bidang pendidikan, evaluasi ada yang bersifat makro dan ada yang mikro. Evaluasi yang bersifat makro sasarannya adalah program pendidikan, yaitu program yang direncanakan untuk memperbaiki bidang pendidikan. Evaluasi mikro sening digunakan di tingkat kelas, khususnya untuk mengetahui pencapaian belajar mahasiswa/ siswa. Pencapaian belajar ini bukan hanya yang bersifat kognitif saja, tetapi juga mencakup semua potensi yang ada pada mahasiswa/ siswa. Jadi sasaran evaluasi mikro adalah program pembelajaran di kelas dan yang menjadi penanggungjawabnya adalah dosen/ guru (Mardapi, 2000:2).

Kirkpatrick salah seorang ahli evaluasi program pelatihan dalam bidang pengembangan sumber daya manusia (SD M). Model evaluasi yang dikembangkan oleh Kirkpatrick dikenal dengan istilah Kirkpatrick Four Levels Evaluation Model. Evaluasi terhadap efektivitas program pelatihan (training) menurut Kirkpatrick (1998) mencakup empat level evaluasi, yaitu: level 1 reaction, level 2 learning, level 3 behavior, dan level 4 result.

Evaluasi terhadap reaksi peserta pelatihan/program berarti mengukur kepuasan peserta (astamer satisaction). Program pelatihan dianggap efektif apabila proses pelatihan dirasa menyenangkan dan memuaskan bagi peserta pelatihan sehingga mereka tertarik termotivasi untuk belajar dan berlatih. Dengan kata lain peserta pelatihan akan termotivasi apabila proses pelatihan berjalan secara memuaskan bagi peserta yang pada akhirnya akan memunculkan reaksi dari peserta yang menyenangkan. Sebaliknya apabila peserta tidak merasa puas terhadap proses pelatihan yang diikutinya maka mereka tidak akan termotivasi untuk mengikuti pelatihan lebih lanjut.

Kirkpatrick (1998:20) mengemukakan "leming can be defined as the extend to which partiajpans dhangeattitudes improingknovieelge, and orincreaseskill as a result of attending the program”. Berdasarkan pendapat terdapat tiga hal 
yang dapat instruktur ajarkan dalam program pelatihan, yaitu pengetahuan, sikap maupun keterampilan. Peserta pelatihan dikatakan telah belajar apabila pada dirinya telah mengalami perubahan sikap, perbaikan pengetahuan maupun peningkatan keterampilan.

Evaluasi pada level ke 3 (evaluasi tingkah laku) ini berbeda dengan evaluasi terhadap sikap pada level ke 2. Penilaian sikap pada evaluasi level 2 difokuskan pada perubahan sikap yang terjadi pada saat kegiatan pelatihan dilakukan sehingga lebih bersifat internal, sedangkan penilaian tingkah laku difokuskan pada perubahan tingkah laku setelah pesenta kembali ke tempat kerja. Kriteria keberhasilan pada evaluasi level ke 3 adalah perubahan sikap yang telah terjadi setelah mengikuti pelatihan akan diimplementasikan setelah mahasiswa mengikuti perkuliahan, sehingga penilaian tingkah laku ini lebih bersifat eksternal. Evaluasi hasil dalam level ke 4 ini difokuskan pada hasil akhir (final reelt) yang terjadi karena peserta telah mengikuti suatu program. Dalam kegiatan pembelajaran model evaluasi ini mengarah pada hasil akhir yang diperoleh mahasiswa.

Evaluasi dilakukan untuk memperoleh gambaran atau informasi tentang hasil dan proses belajar peserta didik, serta mengetahui kesulitankesulitan yang muncul pada saat proses belajar mengajar berlangsung. Evaluasi juga berkaitan erat dengan proses penilaian baik itu penilaian hasil belajar maupun penilaian proses. Evaluasi berfungsi untuk mengembangkan suatu program pembelajaran yang meliputi desain belajar mengajar. Evaluasi juga berfungsi untuk menetapkan kedudukan suatu program pembelajaran berdasarkan ukuran/ kriteria tertentu,sehingga suatu program dapat dipercaya, diyakini dan dapat dilaksanakan terus, atau sebaliknya program itu harus diperbaiki atau disempurnakan.

Evaluasi merupakan salah satu kegiatan utama yang harus dilakukan oleh seorang pendidik dalam kegiatan pembelajaran. Dengan penilaian, pendidik akan mengetahui perkembangan hasil belajar, intelegensi, bakat khusus, minat, hubungan sosial, sikap dan kepribadian siswa atau peserta didik. Evaluasi itu sendiri dalam kaitannya dengan pembelajaran akan berpengaruh terhadap apakah tujuan pembelajaran itu tercapai atau tidak. D engan demikian kegiatan evaluasi sangat penting untuk mengukur sejauh 
mana keberhasilan mahasiswa maupun pendidik dalam proses belajar mengajar.

Kegiatan asesmen merupakan unsur utama dalam kegiatan belajar mengajar. Asesmen merupakan proses pengumpulan informasi yang dilakukan secara sistematis dan terukur, baik itu bersifat kualitatif maupun kuantitatif. A sesmen digunakan untuk memberikan informasi kepada siswa tentang bagaimana yang mereka kerjakan atau sejauhmana penguasaan mereka dalam pembelajaran (Garfield, 1994). Asesmen juga merupakan proses untuk memperoleh informasi tentang pengetahuan matematika siswa, kemampuan membuat kesimpulan untuk berbagai tujuan (NCTM, 1995). A sesmen memiliki visi penting yaitu sebagai suatu proses dinamis yang secara kontinu menghasilkan informasi tentang kemajuan prestasi siswa yang tercantum dalam tujuan pembelajaran (G arfield, 1994).

Penilaian (assessment) memiliki makna yang berbeda dengan evaluasi. The Task Group on Assessment and Testing (TGAT) mendesknipsikan asesmen sebagai semua cara yang digunakan untuk menilai unjuk kerja (performance) individu atau kelompok (Griffin dan Nix, 1991:3). Popham (1995:3) mendefinisikan asesmen dalam konteks pendidikan sebagai sebuah usaha secara formal untuk menentukan status siswa berkenaan dengan berbagai kepentingan pendidikan. Boyer dan Ewel dalam Stark dan Thomas (1994:46) mengemukakan assessment is processes that provide information about individual students, about curricula or programs, about institutions, or about entire systems of institutions.

Asesmen sebagai proses yang menyediakan informasi tentang individu siswa, tentang kurikulum atau program, tentang institusi atau segala sesuatu yang berkaitan dengan sistem institusi. Berdasarkan pendapat para ahli tersebut disimpulkan bahwa asesmen atau penilaian merupakan kegiatan menafsirkan data hasil pengukuran. Asesmen atau penilaian dilakukan berdasarkan karakteristik mahasiswa dan matakuliah yang diajarkan.

Penelitian ini akan mengimplementasi Evaluasi Model Kirkpatrick pada pembelajaran Masalah Nilai Awal dan Syarat Batas bagi mahasiswa matematika Jurusan Pendidikan Matematika Fakultas MIPA Universitas Negeri Gorontalo. Dari empat level evaluasi model Kirkpatrick, masing- 
masing dibuat assesmen tersendiri. Pada level reaksi (Evaluating Reaction) proses pembelajaran melibatkan pemanfaatan IT berupa software Maple dengan jenis kegiatan praktikum (melakukan pemodelan) untuk menyelesaikan masalah-masalah dalam MNA dan Syarat Batas. Pada level evaluasi belajar (Evaluating Learning) maka sistem penilaian menggunakan asesmen kinerja dengan membuat rubrik penilaian. Pada level ketiga dilakukan untuk memperoleh gambaran tentang tingkah laku mahasiswa terhadap kegiatan pembelajaran yang dilakukan. Pada level ke empat lebih ditekankan pada hasil akhir (hasil belajar mahasiswa).

Permasalahan dalam penelitian ini adalah bagaimana implementasi Evaluasi Model Kirkpatrick pada program pembelajaran matakuliah Masalah Nilai Awal dan Syarat Batas, bagaimana efektifitas Evaluasi Model Kirkpatrick dan bentuk asesmen yang digunakan dalam setiap aspek evaluasi. Setiap aspek atau level pada evaluasi model Kirkpatrick dilakukan dengan model asesmen atau penilaian yang berbeda. Hal ini dilakukan untuk mendapatkan gambaran secara umum terhadap kemampuan yang dimiliki oleh mahasiswa disetiap kompetensi pada matakuliah Masalah Nilai Awal dan Syarat Batas. Hasil yang diperoleh pada setiap penilaian, kemudian dilakukan analisis dan deskriptif.

\section{Metode Penelitian}

Penelitian ini dilakukan untuk mendapatkan gambaran tentang implementasi Evaluasi Model Kirkpatrick pada Pembelajaran Masalah Nilai Awal (MNA) dan Syarat Batas bagi mahasiswa jurusan Pendidikan Mahasiswa FMIPA Universitas Negeri Gorontalo. Jenis penelitian ini adalah penelitian deskriptif kualitatif. D ata tentang implementasi Evaluasi Model Kirkpatrick dijaring dengan beberapa instrumen. Untuk level pertama dari evaluasi model Kirkpatrick, dijaring dengan menggunakan angket. Angket yang digunakan terlebih dahulu dilakukan estimasi reliabilitas angket dengan Crombach's Alpha. Sedangkan data hasil belajar mahasiswa dijaring berdasarkan asesmen yang digunakan dalam proses pembelajaran. 
Subjek dalam penelitian ini adalah mahasiswa Jurusan Pendidikan Matematika Fakultas Matematika dan Ilmu Pengetahuan Alam Universitas Negeri Gorontalo angkatan 2007/ 2008 yang memprogramkan matakuliah MNA dan Syarat Batas. Jumlah populasi dari penelitian ini adalah 126 orang yang terbagi menjadi empat kelas. Sedangkan sampel dalam penelitian ini adalah mengambil dua kelas dari total populasi yang ada. Jumlah sampel dalam penelitian ini adalah 58 orang.

Prosedur penelitian merupakan mekanisme yang dilakukan selama pelaksanaan penelitian dilakukan. Prosedur penelitian dilaksanakan dengan tahapan-tahapan seperti pada Tabel 1.

Tabel 1. Tahapan-tahapan Penelitian

\begin{tabular}{|c|c|c|}
\hline No & Tahapan Penelitian & Aktifitas \\
\hline \multirow{4}{*}{1.} & \multirow{4}{*}{ Tahap Persiapan Penelitian } & Menetapkan Materi Pembelajaran \\
\hline & & Menyusun panduan praktikum \\
\hline & & Menyiapkan rubrik penilaian \\
\hline & & Menyiapkan angket \\
\hline \multirow{3}{*}{2.} & \multirow{3}{*}{$\begin{array}{l}\text { Tahap Pelaksanaan } \\
\text { Penelitian }\end{array}$} & Melaksanakan proses pembelajaran \\
\hline & & $\begin{array}{l}\text { Melaksanakan kegiatan praktikum sebagai bagian } \\
\text { dari evaluasi proses }\end{array}$ \\
\hline & & $\begin{array}{l}\text { Menilai hasil kerja mahasiswa melalui asesmen } \\
\text { kinerja (rubrik) sebagai bagian dari evaluasi } \\
\text { belajar }\end{array}$ \\
\hline \multirow{6}{*}{3.} & \multirow{6}{*}{ Tahap Akhir Penelitian } & Melakukan Pengumpulan Data \\
\hline & & Melakukan Pengujian D ata \\
\hline & & Melakukan Analisis D ata \\
\hline & & Melakukan pembahasan dari hasil analisis data \\
\hline & & Menyusun laporan penelitian \\
\hline & & Membuat artikel penelitian \\
\hline
\end{tabular}

Pengumpulan data dalam penelitian ini dilakukan untuk masingmasing aspek pada evaluasi Model Kirkpatrick. Pada penelitian ini masingmasing aspek menggunakan penilaian tersendiri. Evaluasi program pembelajaran pada matakuliah Masalah Nilai Awal dan Syarat Batas dilakukan empat aspek yaitu Evaluasi Reaksi (Evaluating Reaction), Evaluasi Belajar (Evaluating Leming, Evaluasi Tingkah Laku (Evaluating Bdhavia), dan Evaluasi Hasil (Evaluating Result). Dalam melakukan penilaian 
obyektifitas dipertahankan atau diutamakan, sehingga setiap penilaian perlu dibuat rubrik atau kriteria penilaian. Evaluasi Reaksi (Evaluating Readion) dilakukan dengan readion shet dalam bentuk angket sehingga lebih mudah dan lebih efektif.

Pengumpulan data untuk evaluasi belajar dilakukan melalui asesmen kinerja, dengan membuat rubrik penilaian. Rubrik atau kriteria penilaian merupakan suatu deskripsi tentang dimensi-dimensi untuk memutuskan kinerja mahasiswa, skala nilai dan standar untuk memutuskan kinerja. Jenis rubrik yang digunakan dalam evaluasi kinerja terbagi dua bentuk yaitu rubrik holistik untuk menggambarkan kualitas kinerja dan rubrik analitik memberikan nilai untuk komponen tugas. Rubrik penilaian yang digunakan dalam penelitian ini adalah rubrik holistik seperti pada Tabel 2.

Tabel 2. Rubrik Kriteria Penilaian

\begin{tabular}{|c|c|}
\hline Tingkat & Kriteria Umum \\
\hline $\begin{array}{l}4 \\
\text { (Sangat } \\
\text { Memuaskan) }\end{array}$ & $\begin{array}{l}\text { Menunjukkan pemahaman yang lebih terhadap konsep, } \\
\text { Menggunakan strategi-strategi yang sesuai, } \\
\text { Komputasinya (pemitungan) sesuai, Penjelasannya baik, } \\
\text { Diagram/ tabel/ grafik tepat, Melebihi pemecahan } \\
\text { masalah yang dinginkan }\end{array}$ \\
\hline $\begin{array}{l}3 \\
\text { (memuaskan } \\
\text { dengan sedikit } \\
\text { kekurangan) }\end{array}$ & $\begin{array}{l}\text { Menunjukkan pemahaman tehadap konsep-konsep, } \\
\text { Menggunakan strategi yang sesuai, Komputasi } \\
\text { (perhitungan) sebagian besar benar, Penjelasan efektif, } \\
\text { Diagram/ tabel/ grafik sebagian besar benar, Memenuhi } \\
\text { semua pemecahan masalah }\end{array}$ \\
\hline $\begin{array}{l}\text { (cukup } \\
\text { memuaskan } \\
\text { dengan banyak } \\
\text { kekurangan) }\end{array}$ & $\begin{array}{l}\text { Menunjukkan pemahaman temadap sebagian besar } \\
\text { konsep-konsep, Tidak menggunakan strategi yang } \\
\text { sesuai, Komputasi (perhitungan) sebagian besar benar, } \\
\text { Penjelasan memuaskan, Memenuhi sebagian besar } \\
\text { pemecahan masalah yang diinginkan }\end{array}$ \\
\hline $\begin{array}{l}1 \\
\text { (tidak } \\
\text { memuaskan) }\end{array}$ & $\begin{array}{l}\text { Menunjukkan sedikit atau tidak ada pemahaman } \\
\text { tehadap konsep-konsep, Tidak menngunakan strategi } \\
\text { yang sesuai, Komputasi (perhitungan) tidak benar, } \\
\text { Penjelaskan tidak memuaskan, diagram/ tabel/grafik } \\
\text { tidak benar, Tidak memenuhi pemecahan masalah yang } \\
\text { diinginkan }\end{array}$ \\
\hline
\end{tabular}

112 - Jumal PenditiandanEvaluas Pendidikan Edisi D ies Natalis ke-48 UNY 
Semua informasi yang diperoleh baik melalui rubrik penilaian melalui asesmen kinerja maupun melalui angket selanjutnya dilakukan analisis baik secara kualitatif maupun kuantitatif.

\section{Hasil Penelitian}

Implementasi evaluasi model Kirkpatrick dilakukan pada proses pembelajaran pada matakuliah Masalah Nilai Awal dan Syarat Batas. Waktu pembelajaran disesuaikan dengan jumlah sks pada matakuliah MNA dan Syarat Batas. Hasil analisis data pada proses pembelajaran menggunakan evaluasi model Model Kirkpatrick dalam proses pembelajaran matakuliah MNA dan Syarat Batas diuraikan dalam empat aspek evaluasi. Setiap aspek evaluasi dilakukan analisis untuk mendapatkan informasi tentang kemampuan mahasiswa pada matakuliah MNA dan Syarat Batas. D ata yang diperoleh pada setiap level evaluasi, menggunakan penilaian yang berbeda.

\section{Evaluasi Reaksi (E valuating Reaction)}

Program pembelajaran atau proses perkuliahan dianggap berhasil apabila mahasiswa merasa puas terhadap strategi penyampaian materi, media pembelajaran, dan asesmen yang digunakan. Partner (2009) mengemukakan theinterest, attention and motivation of theparticipants arecritical to the success of any trainingprogram peeplelemm better when they react positividy to the leaming eniromment. Disimpulkan bahwa keberhasilan proses kegiatan pembelajaran tidak terlepas dari minat, perhatian, dan motivasi mahasiswa dalam mengikuti jalannya perkuliahan. Mahasiswa belajar lebih baik apabila mereka memberi reaksi positif terhadap lingkungan belajar. Kepuasan mahasiswa terhadap proses pembelajaran yang dilakukan dikaji dari beberapa aspek, yaitu materi yang diberikan, fasilitas yang tersedia, strategi penyampaian materi oleh dosen, dan media pembelajaran yang tersedia.

Gambaran tingkat kepuasan mahasiswa terhadap proses pembelajaran yang dilakukan adalah seperti pada Gambar 1. Dari data tersebut diperoleh presentase untuk kelas A adalah 58,06\% mahasiswa menyatakan sangat memuaskan terhadap proses pembelajaran yang dilakukan, 29,03\% mahasiswa menyatakan memuaskan, 9,68\% menyatakan 
kurang memuaskan dan 3,23\% menyatakan tidak memuaskan. Sedangkan untuk kelas B adalah 48, 39\% mahasiswa menyatakan sangat memuaskan terhadap proses pembelajaran yang dilakukan, 29,03\% mahasiswa menyatakan memuaskan, 6,45\% menyatakan kurang memuaskan dan $3,23 \%$ menyatakan tidak memuaskan.

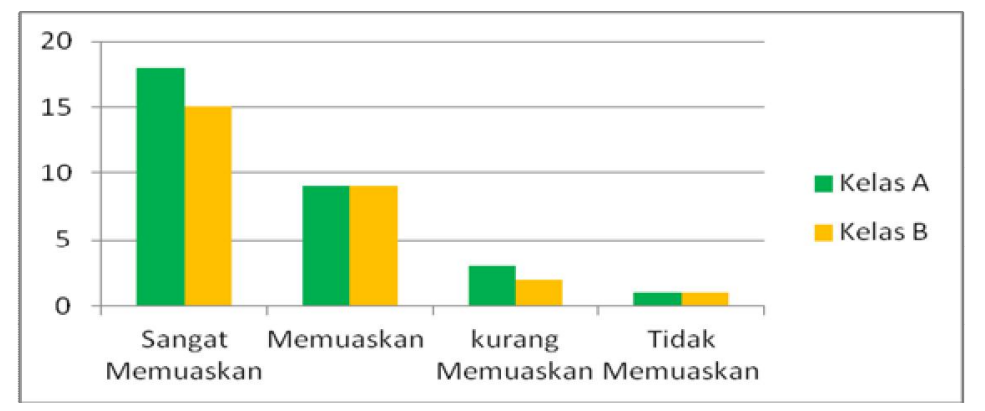

Gambar 1. Hasil Evaluasi Reaksi mahasiswa terhadap pelaksanaan pembelajaran

Dari hasil yang diperoleh seperti pada Gambar 1, maka dapat dikatakan bahwa mahasiswa yang mengikuti kuliah Masalah Nilai A wal dan Syarat Batas memberikan reaksi yang positif terhadap proses pembelajaran yang dilakukan. Evaluasi ini menjadi acuan untuk melakukan perbaikan ataupun peningkatan kualitas proses belajar mengajar oleh dosen.

\section{Evaluasi Belajar (E valuating L eaming)}

Asesmen alternatif diperlukan untuk menilai dimensi proses dan hasil belajar mahasiswa yang tidak diperoleh melalui pemberian atau penilaian melalui tes. Penilaian kinerja yang juga merupakan bagian dari asesmen alternatif bersifat real task situations yang dapat memberikan umpan balik dan sangat bermakna untuk pengembangan potensi yang dimiliki oleh mahasiswa. Para ahli telah memberikan kritikan-kritikan terhadap penggunaan tes tradisional (paper and pencil test) dalam proses pembelajaran. Tes ini hanya untuk menilai pengetahuan ilmiah, tidak mampu mengembangkan potensi yang dimiliki oleh mahasiswa khususnya yang berkaitan kompetensi matakuliah. 
Mengukur efektivitas program pembelajaran perlu untuk melakukan evaluasi belajar (EvaluatingLeming. Evaluasi belajar menyangkut tiga aspek yaitu perubahan sikap, peningkatan pengetahuan maupun perbaikan keterampilan pada mahasiswa. Pembelajaran akan dianggap gagal apabila ketiga aspek tersebut tidak terlaksana atau tidak terjadi perubahan. Penilaian evaluating leaming lebih mengarah pada penilaian hasil (output) belajar. Sehingga dalam penilaian hasil belajar (learning measurement) digunakan asesmen kinerja untuk mengukur pengetahuan yang telah dipelajari, perubahan sikap, dan keterampilan yang telah dikembangkan atau diperbaiki.

Evaluasi belajar pada model Evaluasi Model Kirkpatrick dilakukan dengan asesmen kinerja melalui rubrik penilaian yang telah ditetapkan. Rubrik penilaian individu mahasiswa tergambar pada Tabel 3. Kriteria penilaian dari rubrik pada Tabel 3 mengacu pada Tabel 2. Proses pembelajaran Masalah Nilai Awal dan Syarat Batas dilakukan dengan harapan untuk mengembangkan dan mengungkap seluruh potensi yang dimilki mahasiswa. Hal ini dilakukan mengingat kompetensi dari matakuliah ini sangat bermanfaat bagi mahasiswa untuk melakukan simulasi atau pemodelan yang berkaitan dengan fenomena-fenomena alam atau fenomena kehidupan sehari-hari.

Tabel 3. Rubrik Penilaian Hasil Kerja Mahasiswa

\begin{tabular}{|c|c|}
\hline Kriteria & Mahasiswa \\
\hline Pemahaman konsep & $\begin{array}{llllll}1 & 2 & 3 & 4 & 5 & 6\end{array}$ \\
\hline $\begin{array}{l}\text { Menunjukkan pemahaman terhadap konsep MNA } \\
\text { dan Syarat Batas }\end{array}$ & \\
\hline Kebenaran materi yang disajikan & \\
\hline Penalaran/ Komunikasi & \\
\hline Keterangan jawaban jelas & \\
\hline Sistematika jawaban baik & \\
\hline Komputasi baik & \\
\hline Pemecahan Masalah & \\
\hline Menyusun algoritma yang benar & \\
\hline Hasil simulasi yang baik & \\
\hline Grafik yang sesuai & \\
\hline
\end{tabular}


Evaluasi belajar mahasiswa dilakukan secara individu tentang pengetahuan, sikap dan keterampilan yang dimiliki. Setiap mahasiswa dinilai menggunakan rubrik penilaian berdasarkan Tabel 3. Skor tertinggi dari rubrik yang dibuat adalah 32 dan skor terrendah adalah 8, skor mahasiswa kelas A adalah sebagai berikut :

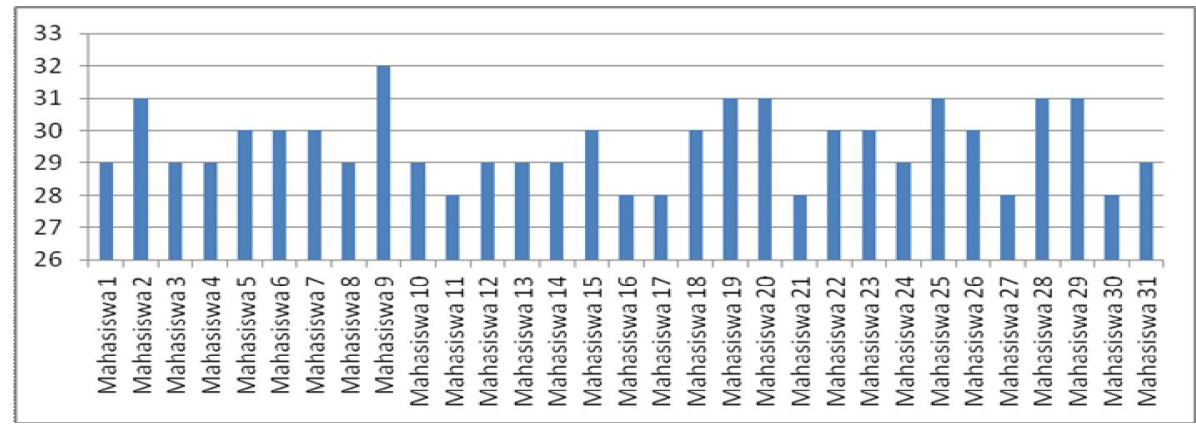

G ambar 2. Hasil Evaluasi Belajar mahasiswa kelas A melalui asesmen kinerja

Rata-rata nilai mahasiswa adalah 29.55 atau 92,33\%. Hal ini menunjukkah bahwa kemampuan mahasiswa kelas A pada matakuliah Masalah Nilai Awal dan Syarat Batas sangat memuaskan. Sedangkan skor mahasiswa kelas B adalah sebagai berikut:

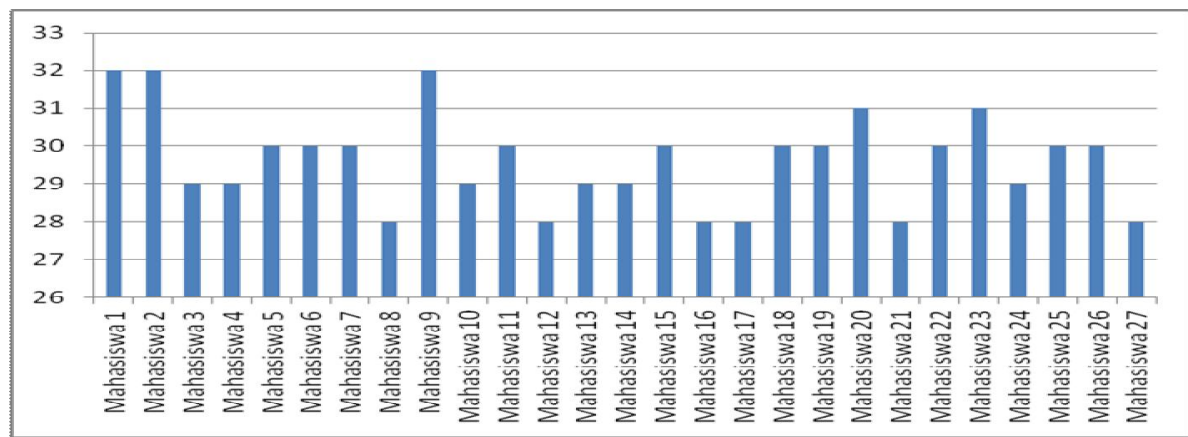

G ambar 3. Hasil Evaluasi Belajar mahasiswa Kelas B melalui asesmen kinerja

Rata-rata nilai mahasiswa adalah 29,63 atau 92,59\%.

116 - Jumal Penditian danEvaluasi Pendidikan E disi D ies Natalis ke-48 UNY 


\section{Evaluasi Tingkah Laku (Evaluating Behavior)}

Evaluasi tingkah laku yang berkaitan dengan proses pembelajaran pada matakuliah Masalah Nilai Awal dan Syarat Batas lebih ditekankan pada perubahan perilaku mahasiswa terhadap manfaat mata kuliah yang diberikan. Evaluasi ini dikatakan berhasil apabila mahasiswa mampu mengimplementasikan materi MNA dan Syarat Batas dalam bentuk pemodelan matematika berdasarkan fenomena alam atau fenomena kehidupan sehari-hari.

Tahapan evaluasi ini dilakukan dengan menilai hasil karya mahasiswa dalam bentuk pemodelan dari konsep-konsep MNA dan Syarat Batas yang berkaitan dengan fenomena alam atau kehidupan sehari-hari. Untuk menilai hasil mahasiswa, maka ditetapkan suatu instrumen penilaian yang dapat menilai kinerja mahasiswa yang berkaitan dengan penerapan konsepkonsep MNA dan Syarat Batas. Pada bagian evaluasi ini peneliti menggunakan rubrik penilaian presentasi kelompok untuk mendapatkan gambaran tentang penerapan konsep-konsep MNA dan Syarat batas. Rubrik yang digunakan sebagai pedoman penilaian adalah seperti pada tabel 4 sebagai berikut :

Tabel 4. Rubrik penilaian proyek Mahasiswa secara kelompok

\begin{tabular}{|c|c|c|}
\hline \multirow[t]{2}{*}{ Kriteria } & Skor & Total \\
\hline & $\begin{array}{llll}4 & 3 & 2 & 1\end{array}$ & \\
\hline Pengetahun/ Pemahaman Konsep & & \\
\hline Konsep-konsep MNA dan Syarat Ba & & \\
\hline model Matematika benar & & \\
\hline Masalah yang dibuat menarik & & \\
\hline Algoritma yang disusun benar & & \\
\hline Komputasi dan Simulasi benar & & \\
\hline Kejelasan Presentasi & & \\
\hline Menggunakan media yang memadai & & \\
\hline Visualisasi presentasi menarik & & \\
\hline Kerjasama semua anggota kelompok & & \\
\hline Menjawab pertanyaan saat diskusi & & \\
\hline
\end{tabular}

Implemetasi Evaluas Modd KIRKPATRICK - 117 
Penilaian proyek mahasiswa berupa artikel tentang pemodelan atau komputasi yang menerapkan konsep-konsep MNA dan Syarat Batas dilakukan dalam bentuk kelompok. D ari 6 kelompok mahasiswa pada kelas A diperoleh hasil seperti pada $\mathrm{G}$ ambar 3. D ata dperoleh dengan melakukan pengamatan pada saat kelompok mahasiswa melakukan presentasi terhadap artikel yang sudah dibuat. Penilaian dilakukan berdasarkan rubrik yang telah disusun, kemudian dilakukan rekapitulasi hasil seperti tergambar pada Gambar 3. Skor tertinggi dari rubrik yang digunakan adalah 36 dan skor terendah adalah 0 . Skor penilaian untuk masing-masing aspek mengikuti rubrik kriteria penilaian pada tabel 2 .

Dari Sembilan aspek yang dinilai pada saaat mahasiswa mempresentasikan hasil artikel tentang aplikasi konsep-konsep Masalah Nilai Awal dan Syarat Batas dalam kehidupan sehari-hari atau fenomena alam lainnya diperoleh skor tertinggi adalah 33, terendah adalah 22 dan rata-rata 27,83 .

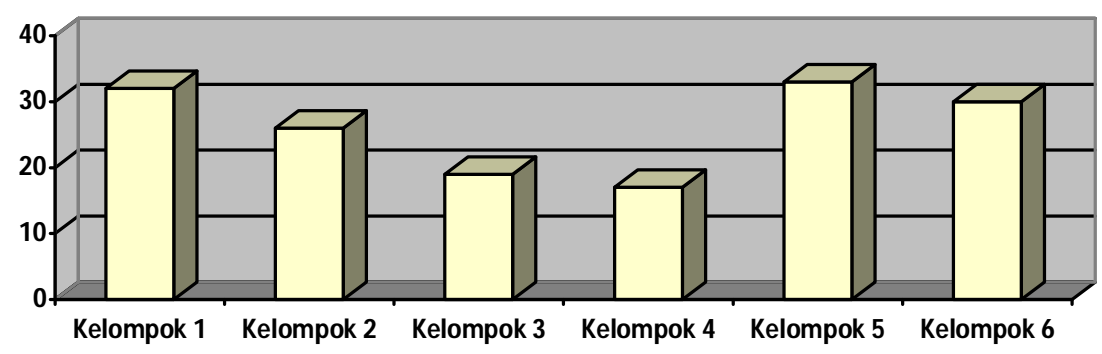

Gambar 4. Skor hasil Penilaian Proyek Mahasiswa kelas A secara Kelompok

Sedangkan rata-rata untuk setiap aspek penilaian proyek mahasiswa kelas A terlihat pada Gambar 5. 


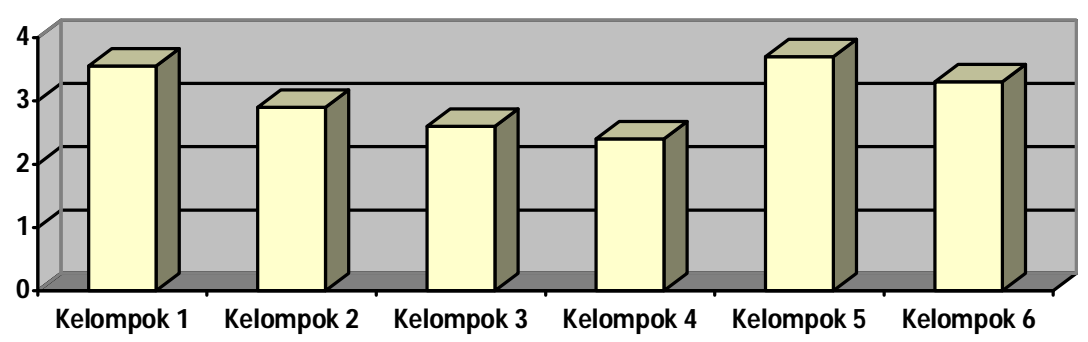

Gambar 5. Rata-rata hasil Penilaian Proyek Mahasiswa kelas A untuk masing-masing aspek

Dengan cara yang sama juga dilakukan pada kelas B, untuk memperoleh data tentang penilaian kinerja mahasiswa yang berkaitan dengan aplikasi konsep-konsep Masalah Nilai Awal dan Syarat Batas dalam kehidupan sehari-hari ataupun fenomena alam lainnya. Dari Sembilan aspek yang dinilai untuk semua kelompok menunjukkan, skor tertinggi adalah 29 dan skor terendah adalah 26 dengan rata-rata adalah 28 . G ambaran tentang skor penialain proyek mahasiswa yang berkaitan dengan aplikasi konsep Masalah Nilai Awal dan Syarat Batas pada Gambar6.

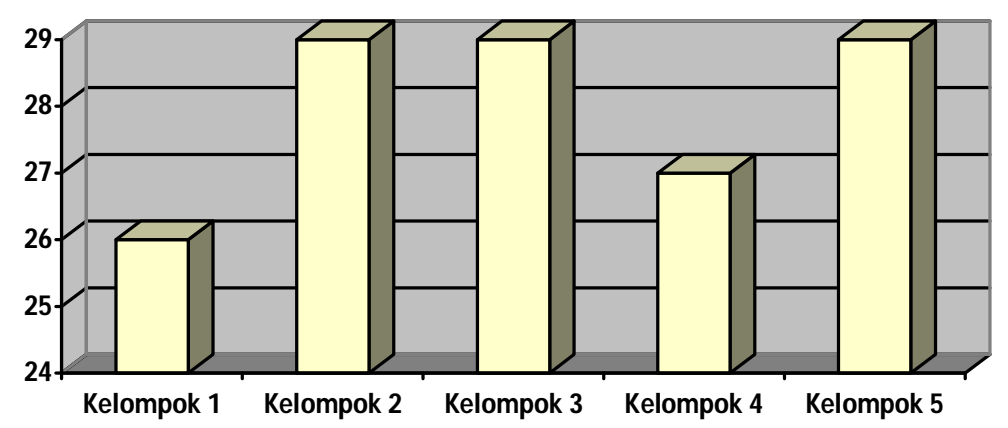

Gambar 6. Skor hasil Penilaian Proyek Mahasiswa kelas B secara Kelompok 
Sedangkan rata-rata untuk setiap aspek penilaian proyek mahasiswa kelas B terlihat pada Gambar 7.

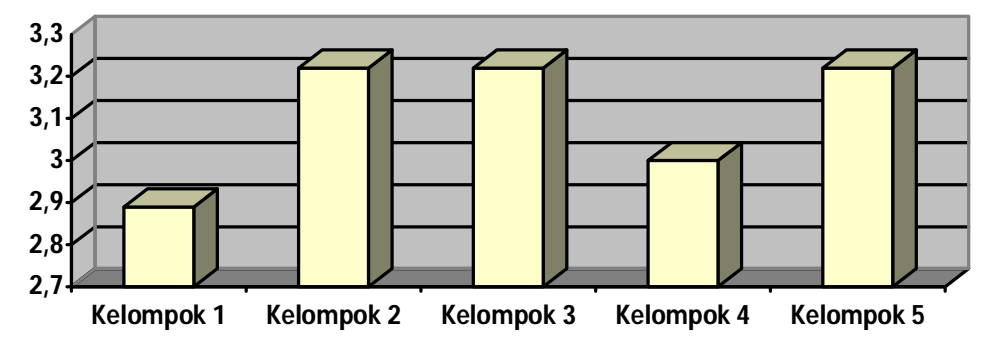

Gambar 7. Rata-rata hasil Penilaian Proyek Mahasiswa kelas B secara Kelompok

\section{Evaluasi Hasil (Evaluating Result)}

Evaluasi hasil (Evaluating Result) berkaitan dengan hasil akhir mahasiswa. Evaluasi ini dikatakan berhasil apabila mahasiswa mampu mencapai nilai akademik yang baik. Nilai akademik mahasiswa dapat dilihat pada Tabel 5.

Tabel 5. D ata Nilai akademik mahasiswa

\begin{tabular}{|l|l|l|l|l|}
\hline No & Kelas & Rata-rata & Standar deviasi & Kriteria \\
\hline 1 & A & 83.84 & 6.63 & Sangat Memuaskan \\
\hline 2 & B & 84.31 & 6.45 & Sangat Memuaskan \\
\hline
\end{tabular}

Rata-rata nilai akademik mahasiswa pada matakuliah Masalah Nilai Awal dan Syarat Batas seperti pada Tabel 5 adalah sangat memuaskan, atau dengan kata lain mahasiswa secara keseluruhan telah memiliki pemahaman yang baik pada matakuliah ini. 


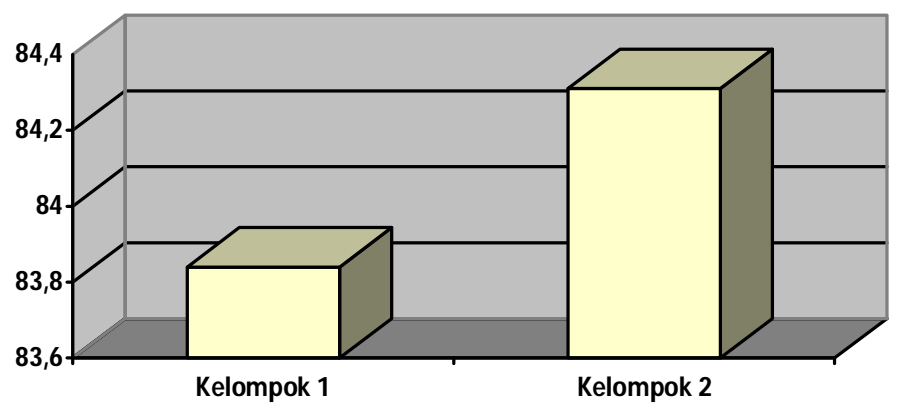

Gambar 8. Rata-rata hasil Akademik Mahasiswa pada matakuliah MNA dan Syarat Batas

\section{Pembahasan}

Berdasarkan hasil analisis data menggambarkan implementasi evaluasi model Model Kirkpatrick pada program pembelajaran matakuliah Masalah Nilai Awal dan Syarat Batas berjalan sesuai dengan yang diharapkan dan dapat memberikan gambaran tentang kemampuan mahasiswa secara keseluruhan. Tingkat pemahaman mahasiswa terhadap materi yang diajarkan pada matakuliah Masalah Nilai A wal dan Syarat Batas sangat memuaskan (tinggi). Dari hasil akhir (nilai akhir) mahasiswa diperoleh informasi tentang kemampuan yang dimiliki oleh mahasiswa. Hal ini disebabkan oleh model evaluasi yang digunakan dapat menjangkau semua aspek yang ada pada masing-masing mahasiswa. Selain itu penilaian yang digunakan tidak hanya dalam bentuk tes tertulis, tetapi penilaian dilakukan berdasarkan asesmen kinerja.

Karakteristik matakuliah MNA dan Syarat Batas yang banyak memerlukan komputasi (simulasi komputer), maka dipandang perlu untuk mengimplementasikan software sebagai alat bantu dalam kegiatan pembelajaran. Dalam penelitian ini kegiatan pembelajaran melibatkan software Maple sebagai salah satu alat simulasi.pemanfaatan software juga dilakukan evaluasi pada mahasiswa yang masuk pada level 1 untuk evaluasi 
Model Kirkpatrick. Dari hasil penelitian yang tergambar pada Grafik 1, menunjukan secara keseluruhan mahasiswa merasa puas atau setuju dengan model pembelajaran yang dilakukan.

Berdasarkan data hasil penelitian yang diperoleh secara umum evaluasi model Kirkpatrick dapat diterapkan untuk mengevaluasi program pembelajaran atau perkuliahan pada matakuliah Masalah Nilai Awal dan Syarat Batas. Hal ini disebabkan empat aspek dalam evaluasi Model Kirkpatrick dapat memberikan gambaran terhadap perubahan sikap, tingkah laku, keterampilan dan hasil akhir mahasiswa pada matakuliah MNA dan Syarat Batas. Selain itu, mahasiswa mulai berani untuk mengungkapkan seluruh potensi yang ada dalam dininya. Mahasiswa menganggap bahwa apapun yang dikerjakan dan berkaitan dengan matakuliah atau konsep MNA dan Syarat Batas, maka akan mendapat penghargaan atau penilaian tersendiri.

Evaluasi untuk matakuliah Masalah Nilai Awal dan Syarat Batas yang berkaitan dengan simulasi dan pemodelan, baik itu yang berkaitan dengan fenomena alam maupun fenomena kehidupan sehari-hari sebaiknya dilakukan dengan model evaluasi yang dapat mengubah sikap atau tingkah laku mahasiswa terhadap karakteristik matakuliah tersebut. D osen dapat melakukan modifikasi terhadap beberapa model rubrik yang sudah ada, disesuaikan dengan karakteristik matakuliah.

Evaluasi program pembelajaran sebaiknya dilakukan oleh setiap dosen atau secara melembaga di tingkat program studi. Hal ini dilakukan untuk melakukan perbaikan proses pembelajaran dan mengembangkan potensi mahasiswa. Evaluasi model Kirkpatrick memiliki empat aspek evaluasi, sangat membantu untuk mendapatkan informasi lebih dari mahasiswa. Setiap aspek evaluasi melibatkan model penilaian yang berbeda. Asesmen kinerja sangat membantu mahasiswa membiasakan diri untuk menunjukkan semua kemampuan yang dimilikinya.

Level pertama evaluasi model Kirkpatrick (Participant Reaction) pada program pembelajaran matakuliah Masalah Nilai Awal dan Syarat Batas berkaitan kepuasan mahasiswa mengenai materi perkuliahan, kualitas atau cara penyampaian materi oleh dosen, dan media pembelajaran. Jadi evaluasi pada level ini lebih focus pada pengukuran kepuasan mahasiswa. 
Level kedua yang diukur adalah aspek pembelajaran mahasiswa yang berkaitan dengan pengetahuan. Pada level kedua mahasiswa yang mengikuti matakuliah Masalah Nilai Awal dan Syarat Batas dinilai kemampuan dan pengetahaunnya melalui asesmen kinerja. Hal ini dilakukan untuk mengetahui semua potensi yang dimiliki oleh mahasiswa.

Level kedua pada evaluasi model Kirkpatrick menjabarkan aspekaspek penilaian secara menyeluruh dan kriteria penilaian yang jelas. Kriteria pemahaman konsep terdiri dari Menunjukkan pemahaman terhadap konsep MNA dan Syarat Batas dan kebenaran materi. Pada kriteria ini ketercapaian mahasiswa diukur pada tingkat penguasaan materi MNA dan Syarat Batas. Penguasaan materi sangat bermanfaat untuk melakukan kegiatan selanjutnya yaitu penyusunan lagoritma dan simulasi.

Level ketiga evaluasi model Kirkpatrick pada program pembelajaran matakuliah Masalah Nilai Awal dan Syarat Batas sangat penting untuk mengukur kemampuan mahasiswa menerapkan atau mengaplikasikan konsep-konsep MNA dan Syarat Batas dalam hal pemodelan yang berkaitan dengan fenomena alam atau fenomena kehidupan sehari-hari. Dalam pembelajaran matakuliah MNA dan Syarat Batas, mahasiswa diberikan kesempatan untuk membuat suatu artikel yang berkaitan dengan pemodel dan menerapkan konsep-konsep MNA dan Syarat Batas kemudian melakukan presentasi. Hasil presentasi menjadi informasi sejauh mana penguasaan mahasiswa terhadapa konsep-konsep yang sudah dipelajari. Level terakhir dari evaluasi model Kirkpatrick pada program pembelajaran Masalah Nilai Awal dan Syarat Batas ditekankan pada hasil akhir dari kegiatan akademik mahasiswa.

Keberhasilan mahasiswa dapat dilihat pada level ketiga dari evaluasi model Kirkpatrick. Kriteria penliaan pada level ini merupakan lanjutan dari penilaian level pertama yaitu pemanfaatan konsep-konsep dalam simulasi dan pemodelan. Mahasiswa membuat model simulasi terhadap salah satu fenomena alam atau fenomena kehidupan sehari-hari dengan menggunakan konsep-konsep MNA dan Syarat Batas. Hasil yang telah diperoleh melalui kegiatan komputasi kemudian dipresentasikan sebagai salah satu aspek penilaian pada rubrik yang telah ditetapkan. 
Evaluasi proses pembelajaran menjadi aspek utama untuk mengetahui seluruh kemampuan yang ada pada masing-masing mahasiswa atau peserta didik. Evaluasi model Kirkpatrick memberikan kemudahan kepada dosen atau pendidik untuk melakukan evaluasi secara menyeluruh terhadap potensi yang dimiliki oleh mahasiswa. Matakuliah MNA dan Syarat Batas yang memiliki karakteristik komputasi dan pemodelan, memerlukan model evaluasi yang mampu mengeksplorasi kinerja mahasiswa secara menyelunuh.

Evaluasi model Kirkpatrick yang diterapkan pada pembelajaran matakuliah Masalah Nilai Awal dan Syarat Batas dengan empat level evaluasi memberikan gambaran tentang kemampuan yang dimiliki oleh mahasiswa. Tingkat penguasaan mahasiswa terhadap suatu obyek atau matakuliah dapat ditentukan dengan beberapa aspek, dengan sistem penilaian yang bervariasi. Sistem penilaian yang bervariasi dapat mengungkap semua potensi atau kemampuan mahasiswa pada setiap indikator dari matakuliah.

Rubrik penilaian yang digunakan dalam setiap level pada evaluasi model Kirkpatrick dapat memberikan motivasi kepada mahasiswa untuk mengungkapkan semua yang diketahui tentang kompetensi pada mata kuliah MNA dan Syarat Batas. Desain proses pembelajaran hendaknya memperhatikan model evaluasi yang digunakan dan bentuk penilaian yang digunakan, untuk mendapatkan gambaran secara menyeluruh dari kompetensi yang dimiliki oleh mahasiswa.

Proses penilaian yang mampu mengungkap semua potensi mahasiswa, dapat menciptakan suasana pembelajaran yang aktif dan efisien. Hal ini disebabkan oleh aktifitas mahasiswa dalam kegiatan pembelajaran lebih tertuju pada kemampuan untuk memecahkan masalah atau mengungkap semua yang diketahui tentang matakuliah yang ada. Berkaitan dengan matakuliah MNA dan Syarat Batas yang melibatkan pemanfaatan IT berupa software pemograman, maka penilaian proyek atau kinerja sangat dibutuhkan. Sistem penilaian yang hanya mengutamakan tes tertulis, akan sulit untuk mengukur keberhasilan mahasiswa terhadap kompetensi dari matakuliah. 
Dalam proses pembelajaran yang dilakukan di perguruan tinggi, dosen berperan sebagai evaluator yang berfungsi untuk mengukur ketercapaian tujuan yang telah dinumuskan dan materi yang telah ditetapkan. D osen sebagai penilai hasil belajar atau proses belajar mahasiswa, hendaknya dapat mengikuti secara kontinu terhadap capaian mahasiswa. Informasi yang diperoleh menjadi umpan balik terhadap proses pembelajaran yang dilakukan. Hasil umpan bailk menjadi acuan dalam memperbaiki dan meningkatkan proses pembelajaran yang dilakukan oleh dosen, dengan demikian akan tercapai pembelajaran yang optimal dan efektif.

Proses evaluasi yang dilakukan oleh dosen untuk matakuliah MNA dan Syarat Batas dapat dilaksanakan pada akhir atau saat proses belajar mengajar berlangsung. Dosen pemberi matakuliah dapat melakukan evaluasi dengan memperhatikan kniteria-kriteria ketuntasan yang diperoleh mahasiswa. Pelaksanaan evaluasi oleh dosen hendaknya dilakukan secara kontinu pada setiap proses pembelajaran. Jika proses evaluasi hanya dilakukan pada akhir pembelajaran, maka proses yang dilakukan selama kegiatan belajar tidak dapat tergambarkan pada hasil akhir mahasiswa. Evaluasi dilaksanakan hendaknya mampu memberikan informasi tentang ketercapaian tujuan yang telah ditentukan. Proses evaluasi yang dilaksanakan harus mampu mengungkap kecerdasan yang dimiliki oleh mahasiswa baik itu kognitif, efektif maupun psikomotorik.

Respon mahasiswa terhadap evaluasi model Kirkpatrick dan rubrik penilaian yang digunakan sangat baik, hal ini ditunjukan dengan hasil kerja mahasiswa secara mandin maupun secara kelompok. Pada evaluasi akademik mahasiswa pun menunjukkan hasil yang baik. Keberhasilan program yang dilaksanakan sangat ditentukan oleh respon dan hasil yang diperoleh mahasiswa. Dalam melakukan evaluasi, evaluator hendaknya memperhatikan aspek-aspek yang hendak dicapai, mahasiswa sasaran dan rubrik penilaian.

\section{Keterbatasan Penelitian}

Penelitian ini dilakukan dengan mengikuti tahapan atau level pada evaluasi model Kirkpatrick, namun terdapat beberapa keterbatasan penelitian 
diantaranya, jumlah sampel atau kelas penelitian terdiri dari dua kelas. Proses pengamatan yang dilakukan dalam setiap aspek pada setiap rubrik dan jumlah mahsiswa yang menjadi sampel menjadi salah satu faktor keterbatasan dalam penelitian ini. Penelitian ini hanya dilaksanakan di Jurusan Pendidikan Matematika Fakultas MIPA Universitas Negeri Gorontalo dengan jumlah sampel 58 orang. Untuk penelitian selanjutnya diharapkan dapat digunakan pada lingkup yang lebih luas baik dari jumlah populasi maupun sampel.

\section{Simpulan}

Dari hasil penelitian dan pembahasan yang telah dilakukan dapat dibuat kesimpulan sebagai berikut:

a. Implementasi Evaluasi Model Kirkpatrick pada program pembelajaran matakuliah Masalah Nilai Awal dan Syarat Batas sangat efektif untuk mengungkap kemampuan yang dimiliki oleh mahasiswa khususnya yang berkaitan dengan kompetensi dari matakuliah.

b. Evaluasi Model Kirkpatrick Mahasiswa mampu membuat mahasiswa untuk mengaplikasikan konsep-konsep Masalah Nilai Awal dan Syarat Batas khususnya dalam pemodelan dan simulasi.

c. Karakteristik matakuliah menjadi dasar untuk menetapkan alat evaluasi dalam pembelajaran. Hal ini berkaitan dengan pengungkapan seluruh potensi yang dimiliki oleh mahasiswa.

d. Pemahaman mahasiswa terhadap suatu matakuliah tidak dapat diukur dengan menggunakan tes tradisional atau hanya mengutamakan tes tertulis, tetapi penilaian kinerja menjadi alternatif untuk mengetahui kemampuan mahasiswa secara menyeluruh. Penilaian kinerja dengan menggunakan rubrik penilaian, dapat menciptakan pembelajaran yang aktif dan kreatif bagi mahasiswa

e. Dalam proses pembelajaran dibutuhkan dosen yang mempunyai kemampuan mengajar dengan baik, dan juga mampu melakukan evaluasi yang efektif. Kegiatan evaluasi menjadi bagian yang tak terpisahkan dari rencana program pembelajaran yang telah ditetapkan.

126 - Jumal Penditian danEvaluasi Pendidikan E disi D ies Natalis ke-48 UNY 
f. Evaluasi proses pembelajaran dilakukan secara menyeluruh, baik dari proses pembelajaran maupun hasil belajar mahasiswa. Penilaian proses pembelajaran dilakukan untuk mengetahui kemampuan mahasiswa terhadap indikator-indikator dari suatu matakuliah.

\section{Implikasi}

Implikasi secara teori dari hasil penelitian ini adalah evaluasi model Kirkpatrick memberikan informasi tentang cara meniali kemampuan mahasiswa secara menyeluruh. Implikasi secara praktis adalah evaluasi model Kirkpatrick merupakan alternatif bagi dosen untuk mendapatkan gambaran tentang kemampuan mahasiswa pada matakuliah MNA dan Syarat Batas atau matakuliah lainnya.

Hasil penelitian ini menunjukkan bahwa dengan menggunakan evaluasi model Kirkpatrick pada proses pembelajaran matakuliah MNA dan Syarat Batas pada Jurusan Pendidikan Matematika FMIPA Universitas Negeri Gorontalo, aktifitas belajar mahasiswa sangat efektif dan mampu mengeksplorasi seluruh kemampuan mahasiswa.

Penelitian ini berdampak pada evaluasi pembelajaran secara umum untuk matakuliah-maakuliah lain dengan karakteristik yang sama. Penilaian dalam setiap proses pembelajaran dilakukan dengan cara yang bervariasi untuk mendapatkan gambaran secara optimal terhadap potensi dalam diri mahasiswa, khususnya yang berkaitan dengan matakuliah tertentu. Hal ini dilakukan untuk meningkatkan hasil belajar mahasiswa.

\section{Daftar Pustaka}

Eko Putro Widoyoko, 2010. Evaluas Progam Penbdajaran,Yogyakarta: Pustaka Pelajar

G arfield, J. B. 1994 Beyand testing and Grading Using Assessment to Improve Student L@ming

Griffin, P., dan Nix, P. 1991. Edurational Assessment and Repating Sydney: Harcout Brace Javanovich Publisher. 
Jumal Penditian danEvaluas Penddikan

Jin Yang and Raul Valdes Cotera, Conceptual Evaluation and Pdigy Deddpments in lifiong leming (UNISCO Institute for Lefelong Learning, G ermmany, 2000) p.24

Johnson R. L. (2009) Assessing PefomAnce: Designing scoing and Validating PeformanceTasks A D ivision of Guilford Publications, Inc. 72 Spring Street, New Y ork, NY 10012

Kirkpatrick, D. L. 1998. Evaluating Training Progams The Four Leds San Francisco: Berrett-Koehler Publisher, Inc.

Madaus, G. F., Scriven, M. S., dan Stuffebeam, D. L. 1993. Evaluation Modds Vieupoints on Educational and Human Sevices Evaluation Boston: Kluwer-Nijhoff Publishing.

Mardapi, D. 1999. Pengukuran, Penilaian, dan Evaluas. Makalah disajikan dalam Penataran Evaluasi Pembelajaran Matematika SLTP untuk Guru Inti Matematika di MGMP SLTP, PPPG Matematika Yogyakarta, Y ogyakarta, 8-23 November.

Mardapi, D. 2000. Evaluas Pendidikan Makalah disajikan dalam Konvensi Pendidikan Nasional, Universitas Negen Jakarta, Jakarta, 19-23 September.

Mardapi, D . 2003. Kunikulum2004 dan Optimalisasi SistemEvaluas Pendidikan di Sdkdah Makalah disajikan dalam Seminar Nasional Kurikulum 2004 Berbasis Kompetensi, Universitas A hmad Dahlan, Yogyakarta, 10 Januari.

Mokhtari, K. Yellin, D. Bull, K. Montgomery, D. (1996). Portfolio Assessment in Teacher Education: Impact on Preservice Teachers' Knowledge and Attitudes. Joumal of Teacher Education, Vol 47, (4).

Oliva, P. F. 1992. Dedqping the Cumialum New York: Harper Collins Publishers.

O riondo, L. L., dan Antonio, E. M. D. 1998. EvaluatingEducational Outcomes (Test, Measument, and Evaluation). Florentino St: Rex Printing Company.

128 - Jumal PenditiandanEvaluas Penddikan E disi D ies Natalis ke-48 UNY 
Peterman, F. P (2005) Designing Peformance Assessment Systems for Unban Teacher Preparation LAWRENCE ERLBAUM ASSOCIATES, PUBLISHERS Mahwah, New Jersey London

Popham, W. J. 1995. ClassromAssessment Boston: Allyn and Bacon.

Sriraman, B. \& English, L., (2010). Theries of Mathematics Eduration, Seeking New Frontiers. Springer Heidelberg D ordrecht London New York.

Stark, J. S., dan Thomas, A. 1994. Assesment and Progam Evaluation Needham Heights: Simon \& Schuster Custom Publishing.

Teodoro, V. D., Mathematical modelling in science and mathematics education: Computer Physics Communications 182 (2011) 8-10

Tut, M. A. (2010). An Alternative Approach to Improve Mathematics Performance of Fourth Graders: GA's in Mathematics Education. Procedia Soial andBehavioral Säenes 2 (2010) 2046-2050. 